\title{
Transition care: the link between pediatric rheumatology and adult rheumatology. Data from the experience of the young adult rheumatology ambulatory of Florence
}

\author{
Fernanda Falcini, Federico Bertini, Gemma Lepri, Alessandra Radicati, Marco Matucci Cerinic
}

From 21st European Pediatric Rheumatology (PReS) Congress

Belgrade, Serbia. 17-21 September 2014

\section{Introduction}

Transition from childhood to adolescence is particularly difficult in patients with chronic rheumatic diseases. Moving from pediatric to adult assistance, is not an administrative procedure; it involves a change from of "child-centered" to an "adult-oriented" system, in a delicate phase of life in which emotional stability has not been achieved yet. A structure addressing medical, psycho-social and educational adolescents needs is therefore necessary, representing a link between adult and pediatric rheumatology, in order to maintain the benefits of treatment administered during in childhood.

\section{Objectives}

We report the experience of Young Adults Rheumatology Outpatient of Florence taking charge of the patients in this phase.

\section{Methods}

From January 2000 to May 2014, 754 patients were visited at the Transition Outpatient: 41\% with JIA; 16\% arthralgia; 9\% Raynaud's phenomenon; 6\% SLE; 3\% scleroderma; 2\% connective tissue; $2 \%$ dermatomyositis; Acute Rheumatic Fever (ARF) 2\%; 1\% autoinflammatory syndromes; $18 \%$ others. Of the 311 patients with JIA (93M, 218F), 58.8\% had oligoarticular onset; $21.2 \%$ polyarticular; ERA $13.8 \%$; $4.5 \%$ psoriatic arthritis and $1.6 \%$ systemic onset. Uveitis was found in $29 / 311$ patients, of which $76 \%$ with oligoarthritis.

Department of BioMedicine, Section of Rheumatology, Transition Clinic, University of Florence, Florence, Italy 
Outpatients Clinics to make this transition less dramatic and maintain adherence to therapy and disease control.

\section{Disclosure of interest}

None declared.

Published: 17 September 2014

doi:10.1186/1546-0096-12-S1-P11

Cite this article as: Falcini et al:: Transition care: the link between pediatric rheumatology and adult rheumatology. Data from the experience of the young adult rheumatology ambulatory of Florence. Pediatric Rheumatology 2014 12(Suppl 1):P11.

Submit your next manuscript to BioMed Central and take full advantage of:

- Convenient online submission

- Thorough peer review

- No space constraints or color figure charges

- Immediate publication on acceptance

- Inclusion in PubMed, CAS, Scopus and Google Scholar

- Research which is freely available for redistribution

Submit your manuscript at www.biomedcentral.com/submit 